\title{
Market Transportasi UK: Regulasi atau Kompetisi
}

\author{
Amiruddin Akbar Fisu
}

\author{
Universitas Andi Djemma, Palopo ,Indonesia \\ Amiruddinakbarfisu07@gmail.com
}

\begin{abstract}
ABSTRAK
Tulisan ini merupakan ulasan market transportasi publik yang terjadi di Inggris terutama angkutan bus dan kereta api. Pada bagian awal membahas tentang mekanisme pasar layanan transportasi bus, kemudian bagaimana efek dari deregulasi yang dilakukan pada tahun 1990, serta bagaimana masalah dari deregulasi tersebut. Deregulasi berdampak pada ketidakstabilan pasar, pengaruhnya terhadap service atau layanan, kebijakan subsidi dan persaingan pada rute-rute yang disubsidi, alternative operator, hingga establishing demand pattern dan keinginan penumpang.
\end{abstract}

Kata Kunci: Market transportasi; deregulasi; kompetisi; persaingan

\section{PENDAHULUAN}

Pengoperasian transportasi pasar yang dinamis dibahas dalam Bagian 1. Keuntungan dari persaingan bebas dapat dilihat melalui adanya crossprice elastisitas dan elastisitas layanan [1]. Segmentasi pasar dan penggunaan kebijakan harga juga telah efektif dalam bus, kereta api dan udara pasar . Persaingan adalah dasar dari penjualan sebagian barang dan jasa di bawah gratis kondisi pasar, yaitu yang ditemukan di ' Barat ' masyarakat, dan telah diterapkan pada semua moda transportasi [2].

Namun, ada kelemahan dalam penyediaan layanan yang tidak layak secara finansial, dan intervensi oleh otoritas publik menjadi diperlukan untuk mencapai optimum sosial dan ekonomi ( tidak harus bingung dengan keuangan posisi ) [3] [5].

Di Inggris Office of Fair Trading telah tampak, sampai saat ini , menjadi tidak dapat membedakan antara persaingan yang tidak memberikan penumpang manfaat tapi setelah yang terfokus dan pencapaian net ekonomi manfaat dengan cara non - kompetitif .
Konsep kompetisi sisi penawaran ( atau waralaba, seperti yang ada di London dan pada kebanyakan operasi kereta api - lihat di bawah untuk analisis rinci ) belum diterima OFT kecuali ada persaingan onroad . Bukti menunjukkan bahwa persaingan supply- side memberikan yang lebih baik layanan dan nilai yang lebih baik untuk uang [4]. The OFT telah mengubah pandangannya (meskipun hukum Inggris tetap sama ) dalam kaitannya dengan travelcards dan mengkoordinasikan tiket tetapi membutuhkan independen tiba - di tarif . Ironisnya lebih mudah bagi perusahaan bus untuk menggabungkan daripada layanan koordinasi , yang banyak operator kecil mungkin ingin lakukan . Analisis efek dari kontrak kualitas luar London akan memberikan kesempatan bagi siswa untuk menguji manfaat persaingan bebas terhadap terkoordinasi jaringan waralaba [6].

Bab ini menempatkan argumen terhadap persaingan pasar bebas murni tetapi menetapkan alternatif - model kompetitif supply - side - dipertimbangkan . Model ini menyiratkan , dalam istilah ekonomi [7], penggunaan kekuatan pasar untuk mengidentifikasi permintaan, penggunaan 
tender yang kompetitif ( banyak digunakan di sektor swasta sektor ) untuk meminimalkan biaya dan penggunaan intervensi oleh sektor publik tubuh untuk mengoptimalkan manfaat sosial ekonomi .

\section{THE UK BUS MARKET}

Transportasi Act 1985 dan undang-undang berikutnya (TA 2000 ) menghasilkan perubahan mendasar pengoperasian layanan bus di Inggris ( kecuali London ) selama 20 tahun ( 2004) lalu. Lisensi pelayanan jalan sistem digantikan oleh sistem pendaftaran layanan komersial dan tender untuk layanan yang didukung. Pemegang surat izin operator dapat berjalan layanan bis lokal di mana saja jika ini tidak membutuhkan subsidi asalkan register layanan dengan komisaris lalu lintas [8]. [11] Tidak ada batas waktu pada pengoperasian layanan dan layanan dapat diubah atau dihentikan dengan memberikan pemberitahuan 42 hari ( 56 hari dari tahun 2000 ) kepada komisaris . itu hanya keberatan yang bisa dibuat adalah mereka oleh otoritas lokal di jalan alasan keselamatan atau kemacetan lalu lintas (DOT 1985 , CPT 1986) . di London hampir semua layanan dioperasikan atas dasar bus London Transport Perjanjian berlaku waralaba ditenderkan dari Transportasi untuk London ( TfL ) untuk mengoperasikan salah satu layanannya [9]. Kelayakan finansial layanan apapun mungkin akan terpengaruh oleh non keanggotaannya dari skema TfL Travelcard dan dengan demikian ketidakmampuan untuk menerima pendapatan TfL . Semua layanan TfL ditenderkan adalah Pembatasan perusahaan untuk pra - kualifikasi .

Keputusan untuk mana yang harus disubsidi yang dibuat oleh shire dan kabupaten dewan di Inggris, dewan shire di Wales, regional dan pulau dewan di Skotlandia, Eksekutif Angkutan Penumpang dan TfL . Ini melengkapi jaringan komersial . Sistem subsidi merupakan salah satu yang dapat dioperasikan secara penuh di mana biaya otoritas pendanaan membayar operator dan mempertahankan semua pendapatan , atau atas dasar subsidi net mana Operator menerima pendapatan dan subsidi dibayarkan untuk menutupi sisa biaya . Sistem kontrak biaya penuh memungkinkan dewan untuk mengendalikan nyapengeluaran dengan menyesuaikan tingkat tarif bila diperlukan [10]. Dan tanpa keuangan risiko kepada operator dengan kontrak defisit bersih , operator cenderung untuk mendasarkan mereka tawaran pada asumsi pendapatan yang akan menjadi minimal, sehingga menghindari risiko keuangan dan mungkin menggembungkan harga kontrak. Kedua jenis kontrak memerlukan pemeriksaan pada kualitas layanan dan kehandalan tetapi ' biaya kontrak ' juga membutuhkan cek pada pendapatan. Penyediaan siswa dan orang tua konsesi tarif, pertukaran tiket dan penyediaan rover tiket bagi wisatawan semua menjadi transaksi internal dalam county dewan. Metode ini mungkin adalah yang paling dekat dengan waralaba kompetitif operasi dijelaskan di bawah ini [12].

The White Paper 'Bus' (DOT, 1984) menyatakan bahwa koordinasi dan perencanaan layanan bus pada skala pra1986 adalah tidak perlu dan boros bila proporsi yang signifikan dari layanan bus dapat diberikan secara komersial. Bentuk lama subsidi jaringan persaingan tumpul dan bertindak sebagai disinsentif bagi operator untuk menemukan ide-ide operasi baru dan memotong biaya [13]. Ada sedikit insentif untuk mengembangkan pasar dan operator terhambat oleh peraturan lalu lintas komisaris yang diperlukan operator baru untuk membuktikan kebutuhan akan layanan.

\section{EFEK DEREGULASI}

Deregulasi layanan bus ekspres sejak tahun 1980 menunjukkan bahwa industri itu berpotensi dinamis dan mampu merespon peluang baru. Tanpa regulasi ketat, tarif dapat dikurangi pada banyak layanan bus sementara mereka tetap menguntungkan. Pengalaman ekspres jarak jauh jasa pelatih telah dikurangi tarif , peningkatan frekuensi , tinggi baru layanan berkualitas seperti ' Rapide ' dan operator 
baru memasuki pasar. Jumlah orang yang bepergian sudah naik dan kendaraan baru dengan yang lebih besar kenyamanan telah memasuki pasar . Ini melihat layanan National Express meningkat dari 10 juta penumpang pada tahun 1980 menjadi 15 juta tahun 1985. Namun, pada tahun 1993 , permintaan National Express telah jatuh menjadi 10 juta . itu tarif peningkatan yang signifikan adalah alasan yang disarankan ( Putih , 2003) karena jasa pelatih adalah harga sensitif dan memiliki elastisitas harga tinggi ( -1.0$)$. Ketika tarif yang kemudian dipotong, jumlah penumpang National Express naik menjadi 13 juta per tahun ( 2002) .

Kebijakan deregulasi dibenarkan oleh keberhasilan koridor utama mengungkapkan layanan dan pada gilirannya untuk perpanjangan ke layanan bus lokal.

Unsur pasar pada rute jarak jauh gagal dalam National Ekspres tetap operator dominan karena sifatnya yang komprehensif layanan jaringan, layanan interkoneksi dan pemasaran tersebar luas dan jaringan ritel. Sebagian besar perusahaan kecil tidak mengambil tindakan karena risiko tinggi , kurangnya dorongan kewirausahaan , ukuran kecil perusahaan , bahaya di pindah ke pasar baru ( Hibbs , 1986 ) atau pandangan pesimistis terhadap pasar yang kompetitif . Mereka memutuskan untuk tetap tinggal di kontrak dan operasi menyewa swasta . Kelompok kedua memperkenalkan layanan dan gagal - Sebagian besar operasi mereka antara London dan home base daerah . Ketika beberapa perusahaan membentuk British Coachways di akhir 1980-an mereka tidak bisa bersaing dengan operator mapan . Mereka telah terbatas Pengalaman dalam memasarkan operasi semacam itu dan secara umum tidak menggunakan bus stasiun sebagai memanggil poin. Bahkan ketika National Express tarif meningkat awal 1990-an tidak ada pesaing utama baru muncul ( Putih , 2003).

Konsolidasi layanan diikuti entri awal ke kompetitif pasar , sebagai perusahaan menyadari batas-batas pertumbuhan . Ini mengambil bentuk layanan bersama dan konsentrasi pada koridor ke dan dari London atau sepanjang koridor jalan tol dengan sangat sedikit rute lintas - negara berkembang .

Efek yang paling signifikan dari deregulasi pada layanan operator swasta ' pembangunan telah beroperasi pelatih komuter ke kota-kota besar . nasional Express, antar kota operator pelatih terbesar, bereaksi dengan tarif yang lebih rendah di Menanggapi persaingan dari operator lokal . Perusahaan juga terkonsentrasi pada layanan antar kota langsung dan banyak pemukiman yang lebih kecil ( misalnya di bawah 20.000 ) telah menderita dari penarikan jasa , sehingga perjalanan mengikis peluang. Elastisitas silang pada layanan komuter ke London telah jelas antara perusahaan operasi kereta api dan operator pelatih mana kereta api telah merespon dengan diskon ( 'saver' ') tiket dengan harga elastis pasar dan peningkatan kualitas pelayanan , dengan penyebaran baru , kereta api lebih cepat . Tapi elastisitas harga silang mengakibatkan hilangnya penumpang dan pendapatan dari kereta api sebagai hasil dari deregulasi .

Konsumen telah diperoleh dalam hal tingkat tarif dan peningkatan frekuensi pada rute utama, terutama ke dan dari London . Namun sementara secara keseluruhan ada manfaat bersih , wisatawan tertentu telah terpengaruh, seperti seperti yang di rute pelatih sekunder dengan frekuensi dikurangi atau ditarik layanan ( OECD , 1990). Pengguna kereta api , juga mendapat keuntungan melalui harga yang lebih rendah sementara pemeliharaan kereta frekuensi, kualitas layanan dan investasi di kereta api hanya telah dicapai melalui pemerintah dibantu investasi.

Tarif bus pada umumnya tidak jatuh secara riil . Layanan bis lokal permintaan adalah harga inelastis ( -0.4$)$ dalam jangka pendek , sementara elastisitas layanan ( yaitu reliability) adalah +0.4 . Penurunan permintaan mengikuti deregulasi cenderung telah dihasilkan dari perubahan harga , perubahan tingkat dan frekuensi ( ketidakstabilan ) dan kebingungan ketika di 
beberapa kota-kota lain beberapa perusahaan bus mulai bersaing. Ada penurunan biaya unit tapi ini sebagian besar adalah hasil dari berkurangnya upah

Baru-baru ini bus kilometer telah meningkat di beberapa kota dengan tinggi frekuensi , kendaraan lantai rendah baru, pengurangan tarif di off -peak dan untuk kelompok tertentu ( misalnya anak-anak selama liburan sekolah ) dan konsesi skema tarif .

Persaingan harga telah diperkenalkan di kota-kota berikut baru perusahaan memasuki pasar. Namun, itu hanya berhasil di mana ada permintaan yang tinggi dan frekuensi tinggi dapat dibenarkan .

Dua pasar yang telah diidentifikasi sebagai menunjukkan manfaat deregulasi adalah Oxford dan Brighton . Perusahaanperusahaan bus lokal, City of Oxford Layanan motor Ltd ( Go Ahead Group) dan Stagecoach Oxford, telah di kompetisi sejak akhir 1980 . Dua perusahaan bus dengan pengalaman manajemen yang luas dari kedua operasi bus dan daerah Oxford membawa tarif berkurang, meningkat frekuensi dan peningkatan bus patronase ( salah satu dari beberapa contoh luar ini London ). Telah dikemukakan bahwa peningkatan ini sebagian disebabkan oleh kepemilikan mobil yang rendah di kalangan mahasiswa dan wisatawan di kota dan kerangka langkah-langkah prioritas bus , park and ride skema dan mahal ( $£ 18$ per hari ) mobil parkir di Central Oxford diperkenalkan oleh Oxfordshire County Council dan Oxford Dewan Kota . ( Lihat Bab 2 untuk harga dan faktor elastisitas layanan . ) Kompetisi diperpanjang ke Oxford - London Layanan ekspres dengan tarif yang lebih rendah secara riil dan frekuensi meningkat dari operasi siang hari jam 15 menit kemajuan dengan frekuensi per jam di malam hari. The disbenefits adalah kurangnya integrasi layanan kedua perusahaan , tidak adanya inter ketersediaan tiket, dan kemacetan yang disebabkan di pusat kota Oxford ( terutama di Cornmarket ) .
Keberadaan di Oxford sekarang dari dua kelompok bus utama Inggris, Go Ahead dan Stagecoach, akan menjadikannya sebuah studi kasus yang menarik bagi siswa selama sepuluh tahun ke depan seperti yang telah selama sepuluh tahun terakhir. Brighton memiliki restriktif parkir mobil , tapi satu-satunya operator, Go Ahead, telah mengadopsi positif pendekatan untuk harga dan penyediaan jasa . Kedua komponen memiliki yang kuat gambar lokal. Usulan deregulasi membawa penurunan jangka pendek dalam harga pada beberapa layanan di daerah perkotaan sebagai manfaat dari meningkatnya persaingan yang dicapai . Di daerah pedesaan telah ada inovasi terbatas oleh operator murah menggunakan bus, minibus dan taksi untuk memberikan lebih fleksibel dan Pola responsif layanan dengan penggunaan teknologi tinggi seperti GPS untuk memantau operasi dan memberikan informasi pelanggan real time [25]. Efek yang diharapkan adalah pengenalan pilihan yang lebih besar ke daerah transportasi umum, dengan layanan yang lebih selaras dengan kebutuhan penumpang. Sistem tender baru akan memberikan dewan daerah indikasi yang lebih jelas dari sebelumnya dari biaya mendukung layanan tertentu, sehingga memungkinkan mereka untuk menimbangnimbang jelas biaya dan manfaat dari subsidi dan memberikan nilai yang lebih baik untuk uang untuk subsidi yang mereka berikan [24].

Ironisnya, di daerah di mana perusahaan bus memiliki monopoli layanan komersial dan layanan bus di mana ditenderkan diproduksi oleh beberapa operator, prinsip yang sama ini mungkin berlaku ketika biaya rendah pesaing memasuki pasar. ( Bab 2 dan 4 menggambarkan dampak dalam pasar penumpang maskapai penerbangan .)

\section{MASALAH TENTANG KEBIJAKAN DEREGULASI}

Sejumlah kritik telah dibuat kebijakan ini dan kekhawatiran menyatakan selama masa kebijakan oleh komite parlemen, 
badan konsumen dan industri transportasi penumpang .

Di Inggris pada umumnya penggunaan angkutan umum telah dibuat lebih sulit setelah deregulasi bus . Sementara manfaat jaringan seperti jadwal terpadu dan tiket telah dikenakan oleh peraturan kerangka kerja pada perusahaan yang beroperasi kereta api, di luar London ada kerangka ada untuk industri bus. Banyak dari kurangnya koordinasi telah dipaksakan pada operator dengan peraturan kompetisi membuat informasi sulit untuk memperoleh dan perjalanan selain yang sederhana sulit. Dalam kondisi seperti ini pengguna utama bus mereka yang tidak memiliki mobil yang tersedia ( UKRT , 1997) .

Untuk angkutan penumpang , ada ketegangan antara kompetisi, yang dapat meningkatkan efisiensi pada rute tertentu , dan integrasi, yang sangat penting untuk perjalanan yang melibatkan transfer. Selama beberapa tahun terakhir , deregulasi bus industri dan rel privatisasi, bersama-sama dengan penurunan kekuatan pemerintah daerah, telah menghasilkan layanan yang lebih terfragmentasi dan kurangnya jelas jawab untuk memastikan bahwa manfaat jaringan terjadi . kecuali ini masalah dapat diatasi , potensi manfaat dari persaingan yang meningkat mungkin lebih dari sebanding dengan kerugian ( HOC , 1984).

Hal ini terutama terjadi karena pola dan kegiatan pemanfaatan lahan tidak lagi terkait dengan pola rute radial sederhana dan perjalanan telah menjadi semakin kompleks . Interchange dan koneksi mulus sangat penting jika operator bus kompetitif adalah untuk membawa pengurangan kemacetan dan polusi .

\section{Ketidakstabilan}

Ketidakstabilan di pasar adalah yang pertama dari sejumlah kekhawatiran yang memiliki telah diungkapkan tentang bus deregulasi . Hal ini dimungkinkan di bawah pasar bebas pengaturan bagi perusahaan untuk memasuki dan meninggalkan pasar relatif cepat [20] [23]. Sebuah periode pemberitahuan diperlukan tetapi dalam kasus sebuah perusahaan meninggalkan pasar karena keuntungan rendah atau tidak ada, tidak mungkin untuk terus beroperasi bingung dan mungkin juga tidak beroperasi sama sekali atau memberikan berkurang tingkat yang jauh selama periode pemberitahuan . Bahkan dengan periode pemberitahuan, gerakan ke dalam dan keluar dari pasar, terutama di tahuntahun awal ketika perusahaan sedang menguji potensi pasar dan profitabilitas , akan menyebabkan ketidakstabilan [22].

Apa penumpang membutuhkan adalah pasokan yang stabil dengan kontinuitas pelayanan [21]. Hasil Instabilitas ketika rute, layanan, operator, tarif dan jadwal yang berubah dalam waktu singkat subjek . Ketidakstabilan ini dapat berlangsung selama beberapa cukup periode waktu sebelum keseimbangan baru didirikan. Destabilisation pola mapan layanan kereta api sebagian besar dicegah dengan kontrak waralaba dan terbatasnya penggunaan perjanjian akses terbuka sebagai perusahaan yang beroperasi kereta menanggapi persaingan . usulan mengabaikan efek yang ketidakpastian dan perubahan konstan dalam bus jadwal dapat memiliki tingkat patronase dan meskipun layanan, mungkin lebih responsif terhadap kebutuhan lokal , pendekatan tertentu yang diadopsi akan memperkenalkan ketidakpastian ke dalam transportasi lokal yang tidak menurunkan penggunaan transportasi umum lokal [23].

\section{Koordinasi Layanan}

Para dewan daerah di Inggris dan Wales dalam memiliki tugas untuk mengkoordinasikan transportasi umum . Tapi kebijakan deregulasi akan mempertimbangkan komprehensif perencanaan yang tidak pantas bagi layanan yang dapat disediakan secara komersial . Badan memiliki keberatan dan percaya konsumen harus diberikan keuntungan dari layanan koordinasi dalam hal timing layanan yang kompatibel , informasi jadwal terkoordinasi , dan melalui ticketing sejauh ini mungkin ( HOC , 2004) - Kekhawatiran lainnya adalah bahwa penumpang akan kehilangan manfaat dari 
layanan terkoordinasi sepanjang koridor ; interval antara layanan akan menjadi tidak teratur , tiket tidak akan saling dipertukarkan, koneksi akan hilang, dan publisitas terfragmentasi atau tidak disediakan ( UKRT , 1997).

Kurangnya koordinasi cenderung menjadi ketidaknyamanan tertentu di daerah wisata informasi tidak dapat terus up to date, dan kepercayaan publik dalam sistem akan hilang . Ini akan cenderung bertindak melawan Tujuan mempromosikan industri pariwisata. Banyak dewan daerah juga mendukung mempertahankan tugas mereka saat ini koordinasi dan tidak menjadi otoritas registrasi belaka.

Lainnya menyimpulkan bahwa proposal akan ' lari semua prospek jangka panjang perencanaan terkoordinasi layanan ' dan kabupaten akan terbatas bereaksi dengan kelemahan pasar bebas yang telah ditemukan mampu mengatasi dengan persyaratan mobilitas penduduk pedesaan tersebar luas ditemukan di pedesaan Wales, Skotlandia Highlands atau East Anglia . tender tersebut sistem pengambilan kerugian rute memiliki kelebihan tetapi koordinasi tampaknya an dasar yang efektif untuk tender. Operator kereta api telah menyatakan keprihatinan untuk orang penumpang yang memulai atau mengakhiri perjalanan mereka dengan menggunakan bus lokal layanan . Pemerintah setempat dan operator bus / kereta api , telah (sampai 1985) yang diadopsi kebijakan untuk mendorong peningkatan susun , termasuk pengembangan stasiun bus di terminal kereta api . Ketidakpastian yang dihasilkan mengurangi kesempatan untuk pengembangan susun bus / kereta api dan jadwal terpadu yang menyediakan layanan bus pengumpan lokal, kecuali tersebut ditenderkan layanan .

Dalam pandangan operator (Kreppel, 1997) dan kelompok konsumen (HOC, 2002, 2004), keuntungan dari memperkenalkan kembali koordinasi (yang menekankan Informasi penumpang dan membuat transportasi umum lebih nyaman untuk penumpang) melebihi pembatasan minor yang mengkoordinasikan menempatkan pada operasi pasar bebas (CPT, 1996). Dalam istilah praktis akan memastikan layanan reguler, rencana bus berhenti, mencegah bunching dan ganda parkir bus, dan memastikan bahwa sumber daya digunakan dengan cara yang terbaik.

\section{Competition on subsidised route}

Sebagian besar rute pedesaan bersubsidi yang baik rute radikal dari pusat kota memperluas luar daerah perkotaan, atau rute antar kota yang juga melayani daerah perkotaan di kedua ujung rute. Pendapatan tertinggi hasil per bus mil adalah di daerah perkotaan, akibatnya kompetisi dengan layanan pedesaan bersubsidi akan bertemu pada bagian-bagian dari rute. Gratis persaingan pasar juga akan dikonsentrasikan pada kali hasil tinggi dari hari ( misalnya dari pukul 07.30 sampai 18.30 Senin sampai Jumat ) .

Contoh pada Gambar 13.1 menunjukkan dua layanan komersial, A dan B , beroperasi pada koridor yang sama dengan ditenderkan layanan $\mathrm{C}$. bersubsidi ini pesaing akan pendapatan abstrak dari layanan pedesaan bersubsidi ( C ) dengan dua pilihan kemungkinan :

1. Jika layanan bersubsidi ( C ) harga tetap tinggi maka elastisitas silang faktor akan mengakibatkan penumpang menunggu kendaraan tarif yang lebih rendah ( dioperasikan oleh A atau B ) .

2 . Jika layanan bersubsidi mengurangi tarif untuk bersaing di perkotaan bagian dari rute, subsidi silang internal dalam rute akan berkurang sebagai akibat berkurangnya pendapatan dari sektor perkotaan .

Dimana layanan beroperasi secara komersial murni hanya penduduk bagian perkotaan / pedesaan rute tersebut akan dilayani, sehingga dalam contoh ini operator $\mathrm{A}$ dan $\mathrm{C}$ menghentikan layanan mereka pada akhir daerah built- up .

Setiap layanan ke pusat kota akan terbatas pada jalan-jalan yang cocok untuk operasi bus. Sangat mungkin, karena itu, bahwa subsidi dan layanan komersial akan beroperasi di sepanjang bagian jalan yang sama dan keduanya operator akan 
mengambil dan meletakkan di sepanjang jalan itu. Operator tender untuk layanan bersubsidi akan merasa relatif mudah untuk memperkirakan biaya operasi, tetapi pendapatan akan tergantung pada sejauh mana kompetisi dan ini akan sangat sulit diprediksi, mengingat kemudahan yang baru Operator bisa masuk pasar .

Sebuah dewan county karena itu harus memilih antara dua tarif Pilihan kebijakan untuk layanan bersubsidi dijelaskan di atas [27] . Dalam kedua kasus, ini akan menghasilkan penarikan layanan dianggap perlu secara sosial, atau babak baru tender dengan kemungkinan peningkatan subsidi , kecuali operator komersial menganggap bahwa kembalinya tidak cukup ( karena rute tidak menghasilkan pendapatan yang cukup untuk beberapa operator ), dan sementara itu memberikan pemberitahuan penarikan . Hal ini mungkin mengakibatkan efek merugikan pada layanan yang tidak bisa diatasi dengan pengenalan layanan baru atau jenis baru kendaraan, dan perlindungan bagi layanan bersubsidi dapat dibenarkan .

\section{Cross subsidy}

Ada kecenderungan di ' Bus ' White Paper dan konsekuen saat ini ( 2004) undangundang untuk menganggap subsidi silang sebagai subsidi kerugian membuat rute dengan surplus dari menguntungkan rute, sedangkan bentuk lain dari subsidi silang tidak sepenuhnya dipertimbangkan. Operasi bus puncak dengan tinggi hasil per bus mil akan mensubsidi off peak (10,0015,00 ), malam dan Perjalanan Minggu terutama jika ada biaya yang terkait puncak rendah. Menguntungkan bagian dari rute mendukung bagian yang jarang digunakan : misalnya, di mana pedesaan bagian dari layanan antar - kota disubsidi oleh bagian perkotaan di kedua ujung . Layanan pedesaan dan pinggiran kota berjalan ke pusat-pusat besar penduduk lintas disubsidi oleh bagian perkotaan rute ; layanan musim panas mendukung layanan musim dingin di daerah wisata ; dan perjalanan puncak menjadi pusat kota seperti Chester akan mendukung lebih rendah digunakan perjalanan keluar, meskipun keduanya jasa beroperasi di puncak .

Tingkat subsidi silang dan pentingnya dalam pembiayaan kerugian membuat layanan bus tidak boleh dianggap remeh . Jika kita mempertimbangkan kondisi yang berbeda-beda dari operasi, luas dan penggunaan subsidi silang akan bervariasi bahkan antara dua pusat perkotaan serta antara pedesaan dan perkotaan daerah [26].

Subsidi silang hanya dapat dibenarkan dalam kondisi pasar bebas di mana memberikan kontribusi terhadap profitabilitas. Hal ini dapat terjadi ketika lebih rendah menggunakan jasa dipandang sebagai layanan pengumpan kontribusi ke jaringan utama secara keseluruhan . Perusahaan juga mungkin ingin membuat gambar lokal menyediakan semua lokal layanan dan tidak terlibat dalam ' cherry picking ' yang mungkin akan dikritik [19]. Untuk alasan pemasaran yang sama mungkin tidak ingin perusahaan lain untuk memasuki pasar ( misalnya pada hari Minggu ) untuk mendapatkan pengalaman dari daerah dan mulai bersaing pada rute hari kerja yang menguntungkan ; itu juga akan memungkinkan perusahaan untuk memperbaiki citranya. Dalam kondisi pasar bebas, operator Oleh karena itu hanya akan memilih untuk menjalankan layanan pada rute dan pada waktu yang menguntungkan tetapi dalam beberapa kasus keuntungan ini dapat digunakan untuk subsidi silang terus merugi perjalanan [18] . Keuntungan menghapus subsidi silang adalah bahwa dewan county akan tahu persis berapa banyak itu membayar untuk setiap layanan disediakan [28]. Ini akan dapat membuat keputusan yang lebih baik tentang apakah perjalanan atau rute yang layak disimpan dan untuk menangani kebutuhan dalam sepenuhnya dianggap daftar prioritas . Ini tidak akan menjadi maka peran operator bus untuk membuat ini keputusan atas dasar sosial . Setiap keputusan subsidi oleh operator bus kemudian akan dilakukan atas dasar kriteria operasional atau pendapatan daripada butuhkan. Penghapusan subsidi silang komersial di daerah perkotaan industri dapat 
menyebabkan peningkatan dukungan pendapatan dewan county sementara di daerah pedesaan bagian akan ada sedikit perubahan dalam persyaratan subsidi . apa saja [17]. Oleh karena itu, pengurangan dukungan pendapatan dalam keadaan ini kemungkinan untuk menghasilkan pengurangan di daerah pedesaan, malam dan layanan hari Minggu dan di depot penutupan .

\section{Alternatif operators}

Operator layanan yang kompetitif dan pelayanan sosial ditenderkan akan berasal dari beberapa sumber yang mungkin meskipun ada batas yang dikenakan oleh pengalaman manajerial dan operasional dan jenis kendaraan yang tersedia . itu operator utama setelah deregulasi tidak berbagai operator kecil seperti yang dibayangkan oleh pemerintah hari, tetapi konsentrasi di tangan dari beberapa kelompok [14]. Fakta menunjukkan bahwa sementara mungkin ada beberapa niche operator (CPT 1996 ; HOC ( Badgerline bukti ) 1996) memberikan layanan bus ditenderkan, layanan pedesaan atau spesialis ( misalnya mahasiswa atau rumah sakit ) layanan , mereka tidak mengancam perusahaan besar. Namun tindakan diambil oleh Office of Fair Trading dan Monopoli dan Merger Komisi terhadap operator yang lebih besar untuk predatory pricing dan kegiatan lainnya menunjukkan keyakinan bahwa beberapa kota dapat mendukung dua operator besar yang menguntungkan. Selain kesepakatan untuk tidak bersaing mungkin dibuat antara perusahaan yang tampaknya ' enggan ' untuk bersaing secara langsung dengan satu lain . ( HOC ( bukti OFT ) 1996) .

Dalam kasus operator yang ada , jaringan komersial akan dioperasikan secara menguntungkan memberikan tingkat pengembalian yang memuaskan , sedangkan dewan daerah membuka tender kerugian membuat perjalanan pada tertentu rute , misalnya malam dan layanan Minggu, serta kehilangan membuat pinggiran kota dan layanan pedesaan [38]. Namun, lama didirikan operator panggung kereta mungkin menarik diri dari layanan yang mereka telah beroperasi selama bertahun-tahun karena dari tingkat pengembalian yang rendah dan ketidakpastian pengembalian mendatang yang timbul dari persaingan yang meningkat. Sementara itu, pendatang baru ke pasar telah menemukan bahwa biaya operasi tahap yang jauh lebih tinggi daripada pembinaan atau jalan pengangkutan, misalnya di mana sebuah perusahaan swasta mengambil alih ditenderkan layanan dari kelompok besar (misalnya Pertama, Stagecoach ) anak perusahaan.

Para pengusul deregulasi berpandangan bahwa pola baru layanan akan muncul dari deregulasi yang akan memberikan yang lebih baik layanan bagi masyarakat dan daerah-daerah terpencil. Sudah jelas bahwa ada namun tidak cukup operator alternatif yang sesuai dengan keuangan yang memadai dukungan untuk mengganti operator yang ada[15] [16] . Pasokan bus yang sesuai akan juga tergantung pada pengaturan keuangan untuk penyewaan kendaraan baru atau tingkat pembuangan oleh operator besar dan perusahaan leasing dari kendaraan tangan kedua .

\section{Establishing demand pattern}

Dalam pasar bebas itu untuk penumpang untuk menunjukkan apa yang mereka inginkan atau untuk riset pasar untuk mengidentifikasi kebutuhan dan bagi operator untuk merespon. Dewan county mungkin terlibat dalam mengumpulkan dan membuat tersedia data pasar, dan beberapa telah memimpin dalam hal ini [29]. Perusahaan kecil, terutama di tahuntahun awal, tidak akan memiliki sumber daya atau keahlian untuk melakukan analisis pasar; penumpang tidak akan sepenuhnya menyadari apa layanan yang tersedia, dan tidak ada bukti yang menunjukkan bahwa ketepatan waktu layanan akan meningkatkan [30] [34]. Dalam kondisi seperti ini akan sulit untuk tuntutan penumpang akan membuat perubahan yang dikenal dan sering mengakibatkan dari berbagai layanan yang tidak stabil dapat menyebabkan mereka untuk mencari alternatif perjalanan mode. 
Kesimpulan di bus deregulasi dalam jangka menengah

Dalam menilai keberhasilan atau sebaliknya dari bus deregulasi di Inggris, ketika tujuan pemerintah hari (Konservatif pada tahun 1985) dibandingkan dengan hasil-hasil kebijakan tersebut tidak mencapai utama Tujuan dari peningkatan patronase meskipun beberapa output yang dicapai.

Tabel 13.3

Tujuan kebijakan utama, seperti yang diidentifikasi oleh para menteri pemerintah, untuk menghentikan pengurangan patronase telah gagal.

Ringkasan Deregulasi Bus di Inggris. OECD (1990)

Alasan

- Palang subsidi merugikan menguntungkan rute.

- Dengan kompetisi - lingkup untuk meningkatkan efisiensi.

Efek

- pertumbuhan keseluruhan dalam jarak tempuh.

-Penghematan subsidi bus langsung tetapi peningkatan admin. dan publisitas biaya.

- Tidak ada perubahan harga yang signifikan.

- Akhir ticketing yang terintegrasi (misalnya Travelcards, kecuali Gwynedd Rover Tiket).

- harga besar meningkat dalam beberapa PTE itu.

- sebagian besar masalah organisasi Awal diatasi (misalnya Thames Transit).

- $60 \%$ dari layanan dari operator swasta dibandingkan dengan $8 \%$ sebelum deregulasi. (Banyak ditenderkan tetapi beberapa terdaftar.)

- Penyalahgunaan kekuasaan pasar:
- Predatory pricing;

- Bus penggunaan stasiun.

Pasca-1998

Perubahan kebijakan intervensi pemerintah dalam angkutan umum karena 1990-an telah menempatkan analisis ini ke dalam konteks yang lebih sulit dibandingkan sebelumnya. Siswa harus menggunakan situasi ini sebagai studi kasus untuk mempertimbangkan dampak dari perubahan dalam kerangka busoperasi. Pengenalan konsesi tarif misalnya telah meningkatkan permintaan di beberapa daerah (misalnya Wales) sebesar 5 persen. Intervensi lain seperti jalur bus panjang (misalnya dalam Edinburgh) juga akan meningkatkan waktu perjalanan dan kehandalan dan, melalui efek elastisitas layanan, meningkatkan patronase [37].

\section{A SUPPLY - SIDE COMPETITIVE FRANCHISING SYSTEM}

Tujuan dari kebijakan deregulasi adalah untuk meningkatkan persaingan , mengurangi biaya, mengurangi tarif dan memperoleh nilai uang subsidi angkutan umum . Sudah ada beberapa bukti bahwa biaya dan harga akan berkurang dan total operasi bus akan meningkat pada sibuk rute pada waktu tertentu dari hari . Hal ini juga tampak bahwa kesempatan untuk mengurangi tingkat subsidi secara keseluruhan - terutama di daerah pedesaan - dapat terjadi. Kendaraan lebih cocok juga akan diperkenalkan di daerah di mana subsidi saat ini tinggi atau di mana tidak ada transportasi umum [31]. Masalah praktis proposal saat ini diidentifikasi dalam bab ini adalah ketidakstabilan ; kurangnya koordinasi , penjadwalan dan informasi, dengan beberapa jadwal yang diterbitkan , ' bunching'of bus pada waktu yang populer , ketidakpastian konsumen [32], kurangnya informasi dan berbagai macam kendaraan ; persaingan pada rute bersubsidi terutama pada bagian yang menguntungkan ; dan kesulitan dalam membangun pola permintaan . Lingkungan baru mengasumsikan bahwa akan ada dua 
jaringan - jaringan komersial dan sosial jaringan - tapi untuk alasan yang diuraikan ini bukan pilihan yang bisa diterapkan .[33]

Ada sistem alternatif tujuan yang akan memungkinkan bus layanan yang akan diberikan dalam pasar yang kompetitif, mengurangi biaya operasional dan level support pendapatan , membuat operasi bus lebih banyak permintaan sensitif, meningkatkan nilai uang dan mencegah perusahaan-perusahaan besar yang mendominasi pasar [35]. Tujuan tersebut dapat dicapai dalam kerangka kompetitif namun menghindari ketidakstabilan yang disebutkan di atas. Waralaba akan dikeluarkan oleh otoritas lokal ( yang juga akan menjadi koordinasi dan otoritas subsidi ) untuk rute, sekelompok rute , koridor perjalanan atau daerah kecil . Ini membentuk dasar yang digunakan oleh TfL dan yang lebih dekat dengan waralaba daripada deregulasi . Adopsi menunjukkan bahwa ada variasi antara dua yang dapat memberikan kerangka kerja yang kompetitif lebih baik dari salah satu yang diusulkan.

Waralaba kompetitif akan mencegah kembalinya situasi pra - 1930 dengan banyak operator , perubahan konstan dalam jadwal , dan penumpang kebingungan . Dalam keadaan sekarang pasar penumpang bus dan diberi Kehadiran mobil sebagai alternatif ( yang tidak begitu pada tahun 1920 ) banyak penumpang cenderung perubahan mode . Efeknya akan mengambil kompetisi dari jalan dan sebagai gantinya membangun kompetisi pra - operasional di bawah naungan otoritas waralaba [36].

Suatu bentuk waralaba yang kompetitif dapat memenuhi banyak operasional dan masalah keuangan yang melekat pada posisi deregulasi hadir di Inggris .

Bisa :

- memungkinkan persaingan ;

- menyediakan pasar yang lebih aman di mana restrukturisasi telah menyebabkan beberapa perusahaan dominan ;

- mencegah ketidakstabilan ;
- memungkinkan retensi fungsi koordinasi daerah dewan ' , dan kelangsungan jadwal yang tepat dan operasi rutin ;

- memberikan nilai untuk uang ;

- mengambil persaingan dari jalan , tetapi memungkinkan nilai penuh yang akan dicapai dalam sistem waralaba ;

- memungkinkan pengenalan bertahap proposal ;

- memungkinkan alternatif bentuk waralaba kompetitif untuk dikejar ;

- memungkinkan untuk jaringan bus terpadu ;

- memungkinkan otoritas subsidi untuk memprediksi belanja subsidi yang lebih akurat ;

- mencapai efisiensi tanpa adanya pasar yang tidak stabil.

\section{Karakteristik dari sistem waralaba yang kompetitif}

Ini mungkin sebagai berikut :

- Rute akan ditentukan oleh otoritas waralaba dan tender diundang dari operator potensial. Rute tersebut mungkin menguntungkan atau tidak menguntungkan .

- Operator diberikan kontrak tidak akan harus menghadapi berikutnya kompetisi pada ditentukan selama periode kontrak rute.

- waralaba itu akan diberikan atas dasar subsidi terendah persyaratan untuk kelompok tertentu layanan . Alternatif adalah untuk mengalokasikan jumlah tertentu uang untuk paket layanan dan penghargaan kontrak untuk operator menyediakan tingkat layanan tertinggi .

- Subsidi akan diberikan untuk seluruh periode kontrak.

- Periode kontrak akan tiga sampai lima tahun. Periode minimum adalah ditentukan oleh kebutuhan operator untuk membuat pengembalian investasi dan jangka waktu maksimum harus 
memungkinkan untuk readvertising kompetitif cukup sering untuk mendorong kontraktor untuk memberikan kualitas layanan yang diperlukan oleh penumpang dan waralaba yang otoritas .

- Hak untuk mengembangkan minat anak seperti pemeliharaan kendaraan, iklan dll sebagai fungsi membuat keuntungan .

- Sebuah rencana operasional dan proyeksi keuangan harus disediakan di tahap aplikasi . Kinerja kemudian dapat dipantau terhadap rencana ini .

- Aset seperti bus, garasi dan karyawan dapat ditransfer dari operator kehilangan kontrak untuk operator baru dikontrak pada akhir periode franchise. Hal ini akan memberikan dorongan lebih lanjut untuk kualitas yang lebih tinggi dari peralatan modal untuk dimasukkan dalam operator program investasi .

- Semua pendapatan dan keuntungan , bersama-sama dengan angka subsidi yang disepakati, akan dipertahankan oleh operator. Atau, sebuah waralaba shire county Pengaturan bisa mirip dengan skema LTB hadir di mana kewenangan menerima semua pendapatan tarif dan operator menerima setuju sum untuk menjalankan layanan ini .

- Ukuran setiap operasi waralaba akan cukup kecil untuk memungkinkan perusahaan dari berbagai ukuran untuk bersaing .

Seperti sistem waralaba kompetitif memiliki fitur yang sama dengan yang saat ini dioperasikan di London di mana ia adalah suatu kerangka kerja yang bisa diterapkan untuk kompetisi dan subsidi . Dalam pasar yang kompetitif itu adalah bentuk umum dari memilih operator hotel dan outlet ritel makanan. Hal ini paralel ini dengan operasi waralaba yang sangat kompetitif dan menguntungkan yang digunakan oleh perusahaan high street familiar, seperti rantai makanan cepat saji, yang menyarankan nya kesesuaian untuk aspek kompetitif operasi bus [39] .

Penerapan proses tender yang kompetitif untuk pasar bebas dan operasi bersubsidi dapat kompatibel melalui konsep jaringan waralaba . Rute Individu atau set rute, apakah menguntungkan atau merugi, akan dikelompokkan bersama-sama dan membuka tender atas dasar tiga - tofiveyear kontrak. Ini akan mencapai manfaat kompetisi sambil memberikan stabilitas yang lebih besar dan koordinasi pelayanan. Skema tersebut memiliki luas dukungan di antara berbagai organisasi yang mewakili konsumen dan operator yang menerima nilai persaingan di angkutan umum sebagai sarana Mencapai lebih baik didefinisikan nilai uang dari subsidi bus .

Kerangka waralaba dapat bekerja dengan dewan kabupaten, konsorsium dari kabupaten di otoritas transportasi bersama atau sebuah PTE . Sementara mengurangi Unit biaya, inovasi menggembirakan, mempertahankan manfaat kompetisi itu dapat mempertahankan fitur yang baik travelcards, pemasaran koordinasi bus dan kereta api - dalam jaringan yang memenuhi kebutuhan masyarakat . 


\section{REFERENCE}

[1] Marzaman, L. U., Hafid, Z., Fisu, A. A., \& Nurhijrah, N. (2021). Planning Concept of Lalebbata: Combining Heritage, Policy and Participation. PENA TEKNIK: Jurnal IImiah IImu-IImu Teknik, 6(1), 39-47.

[2] Fisu, A. A. (2016). Potensi Demand Terhadap pengembangan Kanal Jongaya \& Panampu Sebagai Moda Transportasi (Waterway) di Kota Makassar. Jurnal Manajemen Transportasi \& Logistik, 3(3), 285-298.

[3] Tresidder, J. O., POWELL, T., MEYERS, D., \& BURRELL, J. (1968). THE LONDON TRANSPORTATION STUDY: METHODS AND TECHNIQUES. Proceedings of the Institution of Civil Engineers, 39(3), 433-464.

[4] Ridley, T. M., \& Tresidder, J. O. (1970). The London transportation study and beyond. Regional Studies, 4(1), 63-71.

[5] Fisu, A. A. (2018). Analisis Kebutuhan Fasilitas Sisi Laut Pelabuhan terminal Khusus PLTGU Lombok. PENA TEKNIK: Jurnal Ilmiah IImu-ilmu Teknik, 3(2), 197-206.

[6] Humang, W. P., \& Amrin, A. (2018). PENINGKATAN AKSES JALAN UNTUK MENUNJANG DISTRIBUSI HASIL PRODUKSI KOTA TERPADU MANDIRI (KTM) AIR TERANG KABUPATEN BUOL. PENA TEKNIK: Jurnal IImiah IImu-IImu Teknik, 1(2), 111124.

[7] Humang, W. P., \& Zulfadly, A. Z. A. (2016). Analisis Keterpaduan Moda Transportasi Angkutan Penyeberangan Dengan Jalan Raya di Pelabuhan Bajoe Kab. Bone. PENA TEKNIK: Jurnal IImiah IImu-IImu Teknik, 1(1), 27-38.

[8] Fisu, A. A. (2016). Analisis dan Konsep Perencanaan Kawasan Pelabuhan Kota Penajam Sebagai Pintu Gerbang Kab. Penajam Paser Utara kalimantan Timur. PENA TEKNIK: Jurnal IImiah IImu-IImu Teknik, 1(2), 125-136.

[9] Natsir, R. (2016). KARAKTERISTIK KINERJA MODA ANGKUTAN UMUM KOTA PALOPO (STUDI KASUS PENUMPANG BUS EXECUTIVE, SUSPENSI UDARA, SCANIA-PO BINTANG PRIMA). PENA TEKNIK: Jurnal IImiah IImu-ilmu Teknik, 1(2), 155-162.

[10] Syarkawi, M. T., Syafei, I., Munsyir, I., \& Saleh, S. (2021). Analisis Kinerja Angkutan Umum BMA (Studi Kasus Rute Pinrang-Makassar PP). PENA TEKNIK: Jurnal IImiah IImu-IImu Teknik, 4(2), 111-121.

[11] Dahlan, A., \& Trisutomo, S. (2019). Studi Awal Pemanfaatan Kanal Jongaya dan Panampu Sebagai Transportasi Air di Kota Makassar. PENA TEKNIK: Jurnal IImiah IImuIImu Teknik, 4(2), 122-134.

[12] Fisu, A. A. (2019). Tinjauan Kecelakaan lalu Lintas Antar Wilayah Pada Jalan Trans Provinsi Sulawesi Selatan. PENA TEKNIK: Jurnal IImiah IImu-ilmu Teknik, 4(1), 53-65.

[13] Fisu, A. A., Ahmad, A., Hidayat, A., \& Marzaman, L. U. (2020). Potential of mangrove ecosystem as a tourism object development in Kaledupa Island. EDUTOURISM Journal Of Tourism Research, 2(01), 11-17.

[14] Arnol, I. (2018). ANALISIS WAKTU TEMPUH AKTUAL BATAS KOTA MAKASSAR MAROS-MTC KAREBOS. PENA TEKNIK: Jurnal IImiah IImu-IImu Teknik, 3(2), 229-236.

[15] Fuller, D., Sahlqvist, S., Cummins, S., \& Ogilvie, D. (2012). The impact of public transportation strikes on use of a bicycle share program in London: Interrupted time series design. Preventive medicine, 54(1), 74-76.

[16] Nurhijrah, N., \& Fisu, A. A. (2020). Place Memory Masyarakat pada Bangunan Cagar Budaya di Kota Palopo. RUAS (Review of Urbanism and Architectural Studies), 17(2), 6370.

[17] Ahmad, A., Fisu, A. A., \& Didiharyono, D. (2019). Analisis Potensi Ekosistem Mangrove Sebagai Pengembangan Objek Wisata (Studi Kasus: Kabupaten Wakatobi). Prosiding, 4(1).

[18] Marzaman, L. U., Hafid, Z. A., Fisu, A. A., \& Nurhijrah, N. (2019). PLACE MAKING WORKSHOP BATUPASI SUB DISTRICT PALOPO CITY. To Maega: Jurnal Pengabdian Masyarakat, 2(1), 1-8. 
[19] Hidayat, A., \& Fisu, A. A. (2020). Konsep Arsitektur Panti Rehabilitasi Ketergantungan Narkotika \& Psikotropika Di Makassar, Pendekatan Arsitektur Postmodern Historiscm. PENA TEKNIK: Jurnal IImiah IImu-IImu Teknik, 5(1), 31-43.

[20] Sulaiman, L., \& Fisu, A. A. (2020). Pengaruh Campuran Terhadap Kuat Tekan Beton Agregat Recycle. Rekayasa Sipil, 14(1), 35-42.

[21] HARYONO, H. (2015). COMPARATIVE ANALYSIS OF TRANSPORTATION SYSTEM IN AMERICA, ENGLAND, AND INDONESIA. Jurnal Manajemen Bisnis Transportasi dan Logistik, 1(3), 492-509.

[22] Rowangould, D., Karner, A., \& London, J. (2016). Identifying environmental justice communities for transportation analysis. Transportation Research Part A: Policy and Practice, 88, 151-162.

[23] Fisu, A. A. (2019). Merawat Nilai Membangun Kota.

[24] Marzaman, L. U., \& Fisu, A. A. (2020). Hunian Vertikal Kontainer Buruh Pt Kima Dengan Konsep Arsitektur Humanis. PENA TEKNIK: Jurnal IImiah IImu-IImu Teknik, 5(2), 91-103.

[25] Marzaman, L. U., Hafid, Z., \& FISU, A. A. MERAJUT CERITA DI KOTA TUA (REVITALISASI KAWASAN EX PASAR LAMA PALOPO).

[26] Fisu, A. A., \& Didiharyono, D. (2020, April). Economic \& Financial Feasibility Analysis of Tarakan Fishery Industrial Estate Masterplan. In IOP Conference Series: Earth and Environmental Science (Vol. 469, No. 1, p. 012002). IOP Publishing.

[27] Pardi, M. R., \& Nurmala, R. (2020). Perancangan Aplikasi Reservasi Tiket Bus Menggunakan Aztec Code Berbasis Andorid (Studi Kasus: Po. Bintang Prima). PENA TEKNIK: Jurnal IImiah IImu-IImu Teknik, 5(2), 64-70.

[28] Natsir, R. (2018). EVALUASI KINERJA SIMPANG BERSINYAL DI KOTA PALOPO. PENA TEKNIK: Jurnal IImiah IImu-IImu Teknik, 1(1), 95-100.

[29] Fisu, A. A. (2020). Analisis Perencanaan Pengembangan Fasilitas Terminal Khusus PLTU Nagan Raya Aceh.

[30] Marsus, B., Indriani, N. K., Darmawan, V., \& Fisu, A. A. (2020). PENGARUH PANJANG INFRASTRUKTUR JALAN TERHADAP PDRB DAN PERTUMBUHAN EKONOMI KOTA PALOPO.

[31] Fisu, A. A. (2019). 17 Tahun Kota Palopo: Kota, Manusia dan Para Penggerak.

[32] Nurhijrah, N., Fisu, A. A., Marzaman, L. U., \& Hafid, Z. KONSEP PENATAAN KAWASAN LALEBBATA SEBAGAI KAWASAN HERITAGE DI KOTA PALOPO. Jurnal Arsitektur ZONASI, 4(1).

[33] Fisu, A. A., \& Syabri, I. (2020). Demand Potential On Canal Utilization As Alternative Urban Transportation Medium In Makassar City.

[34] Marzaman, L. U., Hafid, Z., Fisu, A. A., \& Nurhijrah, N. (2021). Planning Concept of Lalebbata: Combining Heritage, Policy and Participation. PENA TEKNIK: Jurnal IImiah IImu-IImu Teknik, 6(1), 39-47.

[35] Fisu, A. A. (2018). ANALISIS LOKASI PADA PERENCANAAN TERMINAL TOPOYO MAMUJU TENGAH. PENA TEKNIK: Jurnal IImiah IImu-IImu Teknik, 3(1), 1-12.

[36] FISU, A. A. STUDI AWAL LOKASI RENCANA PELABUHAN DI TELUK PRIGI KABUPATEN TRENGGALEK.

[37] Arrang, A. T. (2016). TINJAUAN KESELAMATAN LALU LINTAS TERHADAP GEOMETRIK JALAN RUAS TORAJA-PALOPO (STUDI KASUS STA. 379+ 170-STA. 383+ 300). PENA TEKNIK: Jurnal IImiah IImu-IImu Teknik, 1(2), 149-154.

[38] Fisu, A. A., Tufail, D. N., Procyoniana, S. B., \& Nugraha, R. M. (2019). TINJAUAN TRANSPORTASI PADA KAWASAN KOMERSIL (STUDI KASUS JALAN CIHAMPELAS KOTA BANDUNG).

[39] Fisu, A. A., \& Marzaman, L. U. (2018). Pemetaan Partisipatif Kampung Pesisir Kelurahan Tallo Kota Makassar. To Maega: Jurnal Pengabdian Masyarakat, 1(1), 22-28. 